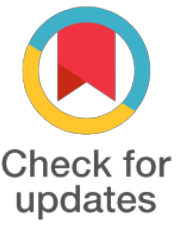

${ }^{*}$ For correspondence:

Competing interests: The authors declare that no competing interests exist.

Received: 2017-08-15 Accepted: 2017-08-25 Published: 2017-09-05

Copyright The Author(s) 2017. This article is published with open access by BioMedPress (BMP).

This article is distributed under the terms of the Creative Commons Attribution License (CC-BY 4.0) which permits any use, distribution, and reproduction in any medium, provided the original author(s) and the source are credited.

\section{Single-Cell Gene Expression Profiling in Breast Cancer Cells with the HER2/neu Gene Knockout by CRISPR-Cas9}

\author{
Xiaoyang (Alice) Wang ${ }^{1}$, Chip Lomas ${ }^{1}$, Michael A. Tycon ${ }^{1}$, Regina Lam², \\ Suzanne Weaver ${ }^{2}$
}

1. BD Biosciences, San Jose, CA, United States

2. BD Genomics, Menlo Park, CA, United States

\section{Abstract}

The HER2/neu gene is amplified and overexpressed in $15-30 \%$ of breast cancers. The overexpression of this oncogene is strongly correlated with decreased survival, increased cancer relapse, and poor prognosis. Therapy has been successfully developed to target this oncogene, yet a better understanding of this oncogene will provide further insight for breast cancer biology and future drug development. In recent years, CRISPR-Casg has emerged as an efficient method for genetic engineering, allowing for targeted gene knockout with minimal off-target effects.

In this study, we employed the CRISPR-Cas9 system to knock out the HER2/neu gene in breast cancer cells. Plasmids with guide RNAs, and Cas9, were transfected into the cells to knock out the HER2 gene. The transfected cells were selected by drug resistance. Then, the cells were sorted into the wells of a 96 -well BD $^{\mathrm{TM}}$ Precise plate. A Whole transcriptome amplification (WTA) assay was performed to obtain a gene expression profile for each cell. In this study, the HER2 gene knockout was performed on T47D, a ductal carcinoma derived breast cancer cell line with no HER2 amplification that shows low to intermediate HER2/neu expression, as well as $\mathrm{SKBR}_{3}$, an adenocarcinoma derived breast cancer cell line known for HER2/neu gene amplification and overexpression. Parental cells without gene editing were also sorted as individual cells for gene expression profiling comparison. The profiling of gene expression in HER2/neu CRISPR-Cas9 knockout cells on a single-cell level might give us insight into the mechanisms in these aggressive cancers that could help future drug discovery for these aggressive cancer types.

\section{Keywords}

Gene expression, Single cell, Cancer cells, cell sorter, next generation sequencing (NGS)

Funding

References 